\title{
Pengembangan Pembelajaran Berbasis Blended Learning Pada Mata Pelajaran Etimologi Multimedia
}

\author{
Maria Dissriany Vista Banggur ${ }^{1}$ \\ Robinson Situmorang ${ }^{2}$ \\ Rusmono $^{3}$
}

\begin{abstract}
The purpose of this study was to develop blended learning-based learning on multimedia etymology subjects. This research develops face-to-face learning combined with online / offline learning and arranged using Edmodo platform. The method used is research and development, with a system approach referring to the Dick Carey and Carey model. The stage of product trials begins with material experts, media experts and learning design experts. Then the product was tested for XMM class students, namely one to one trials, small groups and large groups. The average score of the expert media was 3.52 or good, 4.00 material or very good and 3.73 learning design expert was good. In the testing phase for students the average score for one to one is 3.09, in the small group is 3.01 and in the large group is 3.40. The conclusion of the study is that blended learning-based learning in subjects of multimedia etymology is good and worthy of use
\end{abstract}

Keywords: research and development, blended learning, edmodo, multimedia etymology

\begin{abstract}
Abstrak: Tujuan penelitian ini adalah mengembangkan pembelajaran berbasis blended learning pada Mata Pelajaran Etimologi Multimedia, penelitian ini mengembangkan pembelajaran tatap muka yang digabungkan dengan onlineloffline learning dan disusun menggunakan platform Edmodo. Metode yang digunakan adalah penelitian dan pengembangan, dengan pendekatan sistem mengacu pada model Dick Carey and Carey. Tahap ujicoba produk diawali dengan ahli materi, ahli media serta ahli desain pembelajaran. Kemudian produk diujicobakan kepada siswa kelas XMM, yakni ujicoba one to one, kelompok kecil dan kelompok besar. Hasil penilaian menunjukkan skor rata-rata ahli media 3,52 atau baik, ahli materi 4,00 atau sangat baik dan ahli desain pembelajaran 3,73 berarti baik. Dalam tahap ujicoba kepada siswa hasil skor rata-rata untuk tahap one to one sebesar 3,09, pada tahap kelompok kecil sebesar 3,01 dan pada tahap kelompok besar sebesar 3,40. Kesimpulan penelitian bahwa pengembangan pembelajaran berbasis blended learning pada mata pelajaran etimologi multimedia baik dan layak digunakan.
\end{abstract}

Kata kunci: penelitian pengembangan, blended learning, edmodo, etimologi multimedia

\section{PENDAHULUAN}

Perkembangan teknologi informasi dan komunikasi melaju begitu cepat ke semua sektor kehidupan. Bahkan perkembangannya diperkirakan lebih pesat dari perkiraan semula. Bila melihat sejenak, bagaimana proses belajar berlangsung dalam diri setiap individu, maka ditemukan bahwa proses belajar itu terjadi karena adanya interaksi antara orang yang belajar dengan pesan yang dikemas dalam berbagai medium tertentu. Pesan tersebut bisa itu berupa medium yang sifatnya hanya dimanfaatkan (by

\footnotetext{
${ }^{1}$ Maria Dissriany Vista Banggur, UNJ, HP.0812855178585, email:rinnyadin@gmail,com

${ }^{2}$ Robinson Situmorang, Program Studi Teknologi Pendidikan FIP UNJ, HP. 081510043983

${ }^{3}$ Rusmono, Program Studi Teknologi Pendidikan PPs, UNJ, email@ rusmono.com, HP. 081510043983
} 
utilization), bisa juga yang sengaja dirancang (by design) untuk mencapai tujuan tertentu. Oleh karena itu, belajar dapat terjadi kapan saja, dimana saja, dengan apa saja. Salah satu pertanda bahwa seseorang itu telah belajar adalah adanya perubahan tingkah laku pada diri orang tersebut pada aspek pengetahuannya, keterampilan, atau sikapnya. Apabila proses belajar itu diselenggarakan secara formal di sekolah, tujuannya adalah agar perubahan pada diri siswa berlangsung secara terencana baik dalam aspek pengetahuan, keterampilan maupun sikap sesuai dengan tuntutan kurikulum yang digunakan.

Lembaga pendidikan formal memiliki peranan penting dalam proses adaptasi siswa, hingga menjadi generasi yang tidak tertinggal dengan teknologi yang sangat berkembang begitu pesat. Sekolah kejuruan SMK Fransiskus 1, yang menjadi pusat penelitian merupakan salah satu lembaga pendidikan formal. SMK Farnsiskus 1 dituntut harus mengikuti perkembangan teknologi sehingga mampu menghasilkan lulusan yang kompeten secara pengetahuan, keterampilan, dan sikap. Pengenalan teknologi baru harus dilakukan dalam proses belajar mengajar di SMK agar siswa bisa menjadi kader yang siap menghadapi tantangan dunia di era globalisasi. Kualitas belajar mengajar akan berpengaruh terhadap hasil belajar siswa. Salah satu faktor yang mendukung kualitas pembelajaran adalah ketersediaan sumber dan media pembelajaran yang memadai.

SMK Fransiskus 1 merupakan salah satu sekolah kejuruan yang tidak menerapkan teknologi informasi dan komunikasi dalam pembelajaran. Tersedianya sarana dan prasarana serta fasilitas internet yang memadai tidak benar- benar dimanfaatkan guru dan siswa untuk meningkatkan kualitas pembelajaran. Hal ini disebabkan karena pembelajaran yang digunakan masih menggunakan sistem pembelajaran tatap muka.

Berdasarkan hasil analis awal pada SMK Fransiskus 1 jurusan multimedia, ditemukan beberapa masalah yang harus diteliti. Salah satunya adalah sistem pembelajaran yang digunakan pada SMK Fransiskus 1 jurusan multimedia khususnya pada mata pelajaran etimologi multimedia. Sistem pembelajaran yang digunakan pada umumnya masih menggunakan pembelajaran tatap muka, dimana guru sebagai sumber belajar utama dalam pembelajaran. Di dalam kelas, siswa hanya sebagai pendengar pasif, mendengar dan mencatat apa yang disampaikan guru. Hal ini membuat suasana belajar di dalam kelas terasa kaku, sangat membosankan dan tidak adanya komunikasi aktif antara guru dan siswa. Siswa dihadapkan pada sistem pembelajaran yang sama setiap hari, tanpa adanya sistem pembelajaran lain yang bisa memompa motivasi siswa untuk mengikuti pelajaran dengan penuh semangat. Tentu saja ini menjadi masalah serius karena berpengaruh pada pencapaian kompetensi pembelajaran.

Menanggapi permasalahan di atas, maka diterapkanlah sebuah proses pembelajaran berbasis blended learning dalam pembelajaran di SMK Fransiskus 1 jurusan multimedia khususnya pada mata pelajaran etimologi multimedia. Mengapa harus pembelajaran berbasis blended learning? Blended learning adalah salah satu model pembelajaran yang bisa ditawarkan untuk meningkatkan kualitas pembelajaran. Model pembelajaran ini merupakan gabungan 
antara sistem pembelajaran tatap muka dan online learning. Disatu sisi, ada pembelajaran tatap muka di lingkungan tradisional, disisi lain ada lingkungan pembelajaran terdistribusi yang mulai tumbuh dan berkembang dengan cara-cara eksponensial sebagai teknologi baru yang kemungkinan diperluas untuk distribusi komunikasi dan interaksi. Dengan uraian ini, blended learning dianggap sebagai integrasi pembelajaran tatap muka dan pembelajaran online.

Devrim Akgunduz \& Orhan Akinoglu (2016:113) dalam penelitiaannya menyatakan bahwa blended learning meningkatkan kemandirian keterampilan belajar siswa. Hal ini diyakini bahwa perbedaan yang berarti dibuat oleh blended learning dalam istilah kemandirian belajar bertumbuh dari sebuah perencanaan yang lebih baik dan penggunaan internet secara komprehensif dan efektif. Persamaan dari kegiatan belajar tatap muka dan kegiatan belajar berbasis web dapat memberikan perubahan pada keterampilan belajar siswa dalam kelompok blended learning.

Putra (2015: 12) dalam penelitiannya juga menyatakan bahwa terdapat perbedaan pengaruh yang signifikan antara penerapan model blended learning dan model pembelajaran interaktif terhadap prestasi belajar sejarah pada materi Reformasi siswa kelas XII SMA Negeri di Kabupaten Wonogiri.

Sementara berkaitan dengan penelitian pengembangan Seels \& Richey seperti dikutip oleh (Punaji 2013: 223) menyatakan bahwa Developmental research, as opposed to simple instructional development, has been defined as the systematic study of designing, developing and evaluating instructional program, processes and products that must meet the criteria of internal consistency and effectiveness. Berdasarkan pandangan ini bahwa penelitian pengembangan dalam pembelajaran, tidaklah sama dengan pengembangan instruksional sederhana yang biasa dilakukan guru. Penelitian pengembangan telah didefinisikan sebagai studi sistematis dalam merancang, mengembangkan dan mengevaluasi program pembelajaran. Proses dan produk yang dihasilkan dalam penelitian harus memenuhi kriteria konsistensi internal dan efektivitas. Kriteria ini tentu saja tidak berlaku pada pengeembangan instruksional yang sering dilakukan oleh guru. Pandangan di atas diperkuat oleh definisi penelitian pengembangan (development research) yang dikemukakan oleh Seels \& Richey (1994: 137) yang menyatakan bahwa penelitian pengembangan adalah studi sistematis tentang desain, pengembangan dan evaluasi program, proses dan produk yang harus memenuhi kriteria koatakan bahwa nsistensi internal dan efektivitas.

Sebelum digunakan secara luas, maka produk yang dihasilkan dalam dunia Pendidikan harus valid. Hal dikemukakan Borg and Gall (1983: 772) yang menyatakan bahwa Educational research and development $(R \& D)$ is a process used to develop and validate educational products. The steps of this process are usually referred to as the $R \& D$ cycle, which consists of studying research finding pertinent to the product to be developed, developing the products based on these findings, field testing it in the setting where it will be used eventually, and revising it to correct the definitions found in the field-testing stage. In more rigorous 
programs $R \& D$, this cycle repeated until the field-test data indicate that the product meets its behavioursly defined objectives. Menurut Borg And Gall bahwa penelitian dan pengembangan pendidikan adalah proses yang digunakan untuk mengembangkan dan memvalidasi produk pendidikan. Langkah-langkah dari proses mempalidasi biasanya disebut sebagai siklus R\&D. Beberapa langkah yang perlu dilewati dalam proses ini yakni langkah pertama diawali dengan mempelajari temuan penelitian yang berkaitan dengan produk yang akan dikembangkan. Langkah kedua adalah mengembangkan produk berdasarkan temuan ini. Langkah selanjutnya adalah melakukan pengujian lapangan di mana produk yang dikembangkan akan digunakan pada akhirnya. Langkah terakhir adalah merevisi produk untuk memperbaiki definisi yang ditemukan dalam tahap pengujian lapangan. Dalam kondisi ideal, penelitian pengembangan yang lebih ketat, siklus ini terus diulang hingga data uji lapangan menunjukkan bahwa produk tersebut memenuhi tujuan yang ditentukan.

Sehubungan dengan konsep model, Dewi Prawiradilaga (2012: 33) mengartikan istilah model sebagai tampilan grafis, prosedur kerja yang teratur atau sistematis, serta mengandung pemikiran bersifat uraian atau penjelasan berikut saran. Gustafon dan Branch (2002: 13) mengkategorikan model desain pembelajaran ke dalam tiga kategori terkait dengan penggunaannya, yakni: 1). Classroom-Model Oriented, 2) Product-Oriented Models, dan 3) System-Oriented Models.

Model Dick-Carey (2005: 1) adalah model desain pembelajaran yang dikembangkan oleh
Walter Dick, Lou Carey dan James O. Carey, yang masuk ke dalam kategori system-oriented models. Model Kemp (2013: 12), masuk dalam kategori classroom-oriented models. Model ini terdiri dari 9 tahap yang berkesinambungan satu sama lain sehingga model ini memberikan kebebasan kepada pengembang untuk memulai pada tahap manapun. Model yang mengadaptasi ADDIE ini dikembangkan oleh Barbara Seels dan Zita Glasgow (2002: 42), merupakan contoh dari model pengembangan yang berorientasi pada produk (product-oriented models). Model ini memiliki keunikan tersendiri yaitu menekankan pada manajemen dan memperhatikan keberlanjutan untuk difusi pada hasil.

Thorne (2003:16) mengemukakan bahwa; Blended learning is the most logical and natural evolution of our learning agenda. It suggests an elegant solution to the challenges of tailoring leaning and development to the needs of individuals. It represents an opportunity to integrate the innovative and technological advances offered by online learning with the interaction and participation offered in the best of traditional learning. It can be supported and enhanced by using the wisdom and one-to-one contact of personal coaches. Thorne memaknai bahwa blended learning adalah evolusi paling logis dan alami dari apa yang dapat dilakukan dalam pembelajaran. menurut Thorne bahwa belended learning merupakan solusi elegan untuk mengembangkan tantangan belajar sesuai kebutuhan individu peserta didik. Blended learning adalah peluang nyata untuk mengintegrasikan kemajuan teknologi dan inovasi yang ditawarkan oleh pembelajaran online, dengan interaksi dan partisipasi yang 
ditawarkan dalam pembelajaran tradisional terbaik. Hal ini dapat terjadi apabila ada dukungan untuk peningkatan kualitas melalui kapasitas dan kompetensi guru atau pendidik.

Prendergast (2004:1) menyatakan bahwa blended collaborative learning is essentially a tutor-led distance learning method that blends available face-to-face and online techniques on a foundation framework of facilitated asynchronous conferencing. Menurut Prendergast bahwa blended learning adalah metode belajar jarak jauh adalah pembelajaran yang memadukan pembelajaran tatap muka dan teknik online dengan landasan kerangka kerja yang dikonfigurasi secara asinkron. Sementara Badrul Khan (2005: 202) mengemukakan blended learning combines multiple delivery media that are designed to complement each other and promote learning and application-learned behavior. Pandangan Khan pada dasarnya sama dengan pandangan sebelumnya bahwa blended learning adalah pembelajaran campuran yang menggabungkan beberapa media yang dirancang untuk saling melengkapi untuk meningkatkan kualitas belajar siswa.

Etimologi multimedia merupakan salah satu mata pelajaran kejuruan dasar-dasar multimedia. Berdasarkan struktur kurikulum mata pelajaran etimologi multimedia disampaikan dikelas $\mathrm{X}$ semester 1 dan 2 yang disampaikan dalam waktu 4 jam pelajaran perminggu. Pada semester 1 dan 2 materi etimologi multimedia dibagi menjadi tiga (3) standar kompetensi, yaitu memahami etimologi multimedia yang memiliki kompetensi dasar : mendefenisikan dan mengkategorikan tentang multimedia, mengidentifikasi content (isi) produksi multimedia, mengidentifikasi komunikasi multimedia; memahami alir proses produksi produk multimedia yang memiliki kompetensi dasar : mengilustrasikan pra produksi multimedia, mengilustrasikan proses produksi multimedia, mengilustrasikan proses pasca produksi multimedia; dan merawat peralatan multimedia yang memiliki kompetensi dasar : menjelaskan langkah-langkah perawatan multimedia, membuat kartu perawatan peralatan multimedia.

Edmodo adalah tampilan media sosial yang mirip dengan media sosial yang sudah ada seperti facebook untuk kegiatan pembelajaran sehingga edmodo bagi sekolah dapat berfungsi untuk memberikan catatan, penugasan, kuis, pengumuman, agenda dan penilaian kepada siswa. Edmodo merupakan jejaring sosial untuk pembelajaran berbasis Learning Management System (LMS). Learning Management System yaitu suatu perangkat lunak atau software untuk keperluan administrasi, dokumentasi, laporan sebuah kegiatan, kegiatan belajar mengajar dan kegiatan secara onlinei (terhubung dengan internet). Edmodo memberi fasilitas bagi guru dan murid tempat yang aman untuk berkomunikasi, berkolaborasi, berbagi konten dan aplikasi pembelajaran, pekerjaan rumah (PR) bagi siswa, diskusi dalam kelas virtual, ulangan secara online dan nilai.

Arif (2013) dalam penelitiannya menyatakan bahwa pembelajaran pengetahuan dasar komputer berbasis blended learning dimulai dengan tahapan pembuatan media learning yang content isinya mengkombinasikan perkuliahan tatap muka dengan perkuliahan online. Kemudian melakukan validasi ahli media dan 
validasi ahli materi. Kegiatan yang dilakukan pada setiap tindakan siklus meliputi antara lain: tindakan perencanaan, tindakan pelaksanaan dan observasi serta tindakan refleksi.

Pembelajaran berbasis blended learning menjadi salah satu solusi untuk meningkatkan motivasi mahasiswa pada proses pembelajaran mata kuliah pengetahuan dasar komputer. Peningkatan motivasi belajar tersebut tampak pada hasil total rerata nilai dari siklus I rerata nilainya 16,3 ke siklus II menjadi rerata nilai 18,3 dan stabil pada siklus III dengan rerata nilai 18,3. Peningkatan minat tampak pada aktivitas mahasiswa belajar di dalam kelas dan tampak dalam proses pembelajaran online melalui beberapa aktivitas, antara lain : login, download materi, upload tugas, mengerjakan kuis online, dan menggunakan fasilitas chat/message/inbox, forum diskusi serta partisipasi dalam kegiatan presentasi dan diskusi serta kehadiran kuliah tatap muka. Hasil total rerata nilai aspek minat dari siklus I yaitu 17,9 naik pada siklus II menjadi 26,1 dan pada siklus III naik menjadi 30,8 .

Pembelajaran berbasis blended learning mampu meningkatkan hasil belajar mahasiswa. Para mahasiswa rata-rata pernah mengambil program mata kuliah pengetahuan dasar computer, dengan nilai kurang baik sebelumnya. Oleh karena itu dengan keaktifan tatap muka, diskusi di kelas dan proses belajar mandiri secara online, berdampak pada meningkatnya hasil belajar. Rerata nilai mahasiswa dari siklus I yaitu 74,2 , pada siklus II naik menjadi 84,7 dan pada siklus III rerata nilai meningkat menjadi 88,2.

Sutisna (2016), dalam penelitiannya menge-mukakan: (1) Penggunaan media yang berbasis TIK dalam pembelajaran program paket C di PKBM pada umumnya belum optimal, karena terbatasnya sarana perangkat komputer yang dimilikinya. Sehingga pada waktu pembelajaran tatap muka secara klasikal. penggunaan media oleh tutor masih lemah. (2) Model konseptual pembelajaran blended learning merupakan sebuah model pembelajaran yang menggunakan media CD interaktif dan e-book pada proses belajar mengajarnya, dan sekaligus merupakan sebuah alternatif pembelajaran untuk meningkatkan kemandirian belajar peserta didik program paket C pada PKBM. (3) Hasil implementasi model pembelajaran blended learning yang dikembangkan cukup efektif, di mana berpengaruh $48,2 \%$ terhadap peningkatan kemandirian belajar peserta didik program paket C pada PKBM.

Syarif (2012) dalam penelitiannya menunjukkan ada perbedaan yang signifikan antara motivasi dan prestasi belajar siswa yang menggunakan model blended learning dan siswa yang menggunakan model face-to-face learning, ada peningkatan motivasi dan prestasi belajar siswa yang signifikan akibat penerapan model blended learning, dan tidak terdapat interaksi pengaruh penerapan model pembelajaran dan motivasi terhadap prestasi belajar siswa.

Aeni (2017), dkk dalam penelitiannya menunjukan bahwa (1) Blended learning yang selama ini dilaksanakan menggunakan LMS Edmodo yang hanya diimplementasikan untuk keperluan evaluasi pembelajaran, (2) model blended learning berbasis masalah layak digunakan berdasarkan hasil validasi ahli yaitu persentase validasi silabus $90 \%$ persentase validasi RPP $84,55 \%$ dan validasi e-learning 
83\%, (3) model blended learning berbasis masalah efektif digunakan dalam pembelajaran berdasarkan hasil post test kelas control 77,33 dan rerata post test kelas eksperimen 81,11 . Hasil analisis Uji $\mathrm{t}$ diperoleh nilai thitung $=2,161$ dengan value $=0,03<0,05$ yang berarti bahwa ada perbedaan hasil belajar yang signifikan antara kelas eksperimen dan kelas kontrol.

Hasil yang diperoleh Utami (2017) dalam penelitiannya menyatakan bahwa (1) validitas model blended learning dinyatakan valid pada aspek model pembelajaran, (2) validitas model blended learning dinyatakan valid pada aspek materi, (3) validitas model blended learning dinyatakan sangat valid pada aspek perancangan online learning. Berdasarkan temuan penelitian dapat disimpulkan bahwa model blended learning valid untuk dimanfaatkan sebagai model pembelajaran pada mata pelajaran jaringan dasar. selain itu, dalam penelitian berikutnya Iga Setia Utami juga menyatakan bahwa hasil penilaian praktikalitas model blended learning berdasarkan respon guru adalah $81.66 \%$ (praktis) dan berdasarkan respon siswa adalah $82.75 \%$ (praktis). Berdasarkan temuan penelitian dapat disimpulkan bahwa model blended learning praktis digunakan sebagai model pembelajaran Jaringan Dasar.

Lebih lanjut Bibi \& Jati (2015) dalam penelitiannya menyatakan: pertama, berdasarkan hasil hipotesis I bahwa terdapat perbedaan motivasi belajar mahasiswa pada mata kuliah algoritma dan pemrograman antara mahasiswa setelah mengikuti pembelajaran model blended learning dengan pembelajaran model konvensional, dimana nilai signifikansi sebesar 0,000 lebih kecil dari 0,05. Rata-rata skor motivasi belajar mahasiswa kelas eksperimen sebesar 132,153. Rata-rata skor motivasi belajar mahasiswa kelas kontrol sebesar 126,371. Perbedaan rata-rata motivasi akhir antara kelas eksperimen dan kelas kontrol sebesar 5,782. Perbedaan peningkatan motivasi belajar mahasiswa pada model pembelajaran blended learning ini terlihat dari keaktifan mahasiswa yang terindikasi dengan meningkatnya partisipasi dan perhatian mahasiswa dalam proses pembelajaran. Pengaturan ekternal dari sisi pembelajaran seperti media, bahan, wacana yang disiapkan dapat menarik minat dan potensi mahasiswa untuk belajar yang menunjang munculnya atau tumbuhnya motivasi internal.

\section{METODE PENELITIAN}

Tujuan penelitian ini adalah pengembangan pembelajaran berbasis blended learning pada mata pelajaran etimologi multimedia untuk meningkatkan kompetensi pembelajaran. Penelitian ini akan dilaksanakan di SMK Fransiskus 1 Kampung Ambon - Jakarta Timur. Pembelajaran yang akan dikembangkan adalah pembelajaran berbasis blended learning yang mana menggabungkan pembelajaran tatap muka dengan onlineloffline learning yang disusun sedemikian rupa menggunakan platform edmodo. Strategi penyampaian pembelajaran ini dilakukan dengan tatap muka $70 \%$ dan online/offline learning 30\%, untuk tujuan pembelajaran yang bersifat pemahaman dan pengembangan konsep sangat mungkin dilakukan secara online namun untuk tujuan pembelajaran berupa keterampilan yang menuntut proses belajar dalam bentuk kegiatan praktek maka bentuk pembelajaran yang dipilih 
dalam bentuk tatap muka. Materi pembelajaran yang di blended memungkinkan siswa melakukan pembelajaran secara online, dan proses pembelajarannya sangat menuntut siswa belajar aktif secara mandiri dengan memanfaatkan media edmodo yang telah dirancang sedemikian rupa berupa video pembelajaran, maupun bahan ajar berupa powerpoint maupun file .pdf, .doc, dll.

Merujuk pada tujuan penelitian yang berusaha untuk meningkatkan kompetensi pembelajaran pada mata pelajaran etimologi multimedia, maka metode penelitian yang digunakan adalah penelitian dan pengembangan (research and development). Pendekatan yang digunakan dalam penelitian ini menggunakan pendekatan sistem dimana mengacu pada konsep penelitian dan pengembangan yang dikembangkan oleh Dick dan Carey. Seluruh langkah nantinya akan dilakukan sistematis di mana ketika melakukan langkah selanjutnya, langkah sebelumnya harus sudah diselesaikan terlebih dahulu.

Siklus penelitian Dick Carey and Carey diklasifikasikan menjadi 10 langkah yaitu : 1) mengidentifikasi tujuan pembelajaran; 2) melakukan analisis pembelajaran; 3) menganalis peserta didik dan konteks pembelajaran; 4) menulis tujuan instruksional khusus; 5) mengembangkan instrumen penilaian; 6) mengembangkan strategi pembelajaran; 7) mengembangkan dan menyeleksi materi pembelajaran; 8) merancang dan melakukan evaluasi formatif; 9) melakukan revisi; 10) merancang dan melakukan evaluasi sumatif.

\section{HASIL DAN PEMBAHASAN}

\section{Hasil}

Berikut penjabaran hasil rekapitulasi ujicoba produk pengembangan pembelajaran berbasis blended learning pada mata pelajaran etimologi multimedia untuk siswa SMK Fransiskus 1 yang dinilai oleh ahli media

Tabel 1. Rekapitulasi Ahli Media

\begin{tabular}{|l|c|}
\hline \multicolumn{1}{|c|}{ Komponen } & $\begin{array}{c}\text { Rata-Rata } \\
\text { Penilaian }\end{array}$ \\
\hline Akses & 3,25 \\
\hline Tampilan/Interface & 3,71 \\
\hline Komponen Pembelajaran & 3,50 \\
\hline $\begin{array}{l}\text { Ketepatan/kesesuaian pilihan } \\
\text { komponen pembelajaran } \\
\text { untuk model blended learning }\end{array}$ & 3,60 \\
\hline \multicolumn{1}{|c|}{ Rata-rata } & $\begin{array}{c}\mathbf{3 , 5 2} \\
\text { (Baik) }\end{array}$ \\
\hline
\end{tabular}

Berdasarkan hasil ujicoba yang dilakukan terhadap ahli media diperoleh skor rata-rata 3,52. Hasil ini menyatakan bahwa produk pembelajaran berbasis blended learning dari segi media yang meliputi akses, tampilan/interface, komponen pembelajaran dan ketepatan/ kesesuaian pilihan komponen pembelajaran untuk model blended learning sudah baik.

Tabel 2. Rekapitulasi Ahli Materi

\begin{tabular}{|l|c|}
\hline \multicolumn{1}{|c|}{ Komponen } & $\begin{array}{c}\text { Rata-rata } \\
\text { Penilaian }\end{array}$ \\
\hline Kualitas Materi & 4,0 \\
\hline $\begin{array}{l}\text { Ketepatan/kesesuaian pilihan } \\
\text { komponen pembelajaran untuk } \\
\text { model blended learning }\end{array}$ & 4,0 \\
\hline \multicolumn{1}{|c|}{ Rata-rata } & $\begin{array}{c}\mathbf{4 , 0} \\
\text { (Sangat Baik) }\end{array}$ \\
\hline
\end{tabular}

Berdasarkan hasil ujicoba tahap kedua yang dilakukan terhadap ahli materi diperoleh skor rata-rata 4,0. Hasil ini menyatakan bahwa produk pembelajaran berbasis blended learning dari segi materi yang meliputi kualitas materi dan ketepatan/kesesuaian pilihan komponen 
pembelajaran untuk model blended learning sudah sangat baik.

Tabel 3. Rekapitulasi Ahli Desain Pembelajaran

\begin{tabular}{|l|c|}
\hline \multicolumn{1}{|c|}{ Komponen } & $\begin{array}{c}\text { Rata-rata } \\
\text { Penilaian }\end{array}$ \\
\hline Komponen Pembelajaran & 3.50 \\
\hline $\begin{array}{l}\text { Tujuan pembelajaran } \\
\text { (kompetensi) }\end{array}$ & 3,67 \\
\hline Materi Pembelajaran & 4,0 \\
\hline Strategi Pembelajaran & 3,50 \\
\hline Evaluasi Pembelajaran & 4,0 \\
\hline \multicolumn{1}{|c|}{ Rata-rata } & $\begin{array}{c}\mathbf{3 , 7 3} \\
\text { (Sangat Baik) }\end{array}$ \\
\hline
\end{tabular}

Berdasarkan hasil ujicoba yang dilakukan terhadap ahli desain pembelajaran diperoleh skor rata-rata 3,73. Hasil ini menyatakan bahwa produk pengembangan pembelajaran berbasis blended learning pada mata pelajaran etimologi multimedia dari segi desain pembelajaran yang meliputi komponen pembelajaran, tujuan pembelajaran (kompetensi), materi pembelajaran, strategi pembelajaran dan evaluasi pembelajaran sdah sangat baik.

Tabel 4. Rata-rata nilai Ujicoba one to one

\begin{tabular}{|l|c|c|c|}
\hline \multirow{2}{*}{\multicolumn{1}{|c|}{ Komponen }} & \multicolumn{3}{c|}{ Nilai Rata-rata } \\
\cline { 2 - 4 } & Tinggi & Sedang & Rendah \\
\hline Materi & 3,0 & 2,67 & 3,33 \\
\hline Verbal & 2,0 & 3,0 & 3,0 \\
\hline Visual & 3,0 & 3,0 & 3,5 \\
\hline Video-audio & 3,4 & 3,8 & 3,6 \\
\hline Evaluasi & 3,0 & 3,0 & 3,0 \\
\hline Rata-rata & 2,88 & 3,09 & 3,29 \\
& (Baik) & (Baik) & (Baik) \\
\hline Rata-rata Keseluruhan & \multicolumn{3}{|c|}{3 (Baik) } \\
\hline
\end{tabular}

Uji coba one-to-one dilakukan dengan cara mengujicobakan program aplikasi online kepada siswa secara terpisah. Berdasarkan hasil ujicoba yang dilakukan terhadap tiga orang siswa diperoleh skor rata-rata keseluruhan 3,09. Hasil ini menyatakan bahwa dari segi materi, verbal, visual, video-audio dan evaluasi sudah baik.
Hasil ujicoba one-to-one memberikan gambaran kepada peneliti bahwa produk hasil pengembangan layak untuk dilanjutkan pada tahap ujicoba kelompok kecil. Rekapitulasi ujicoba kelompok kecil ditampilkan pada tabel berikut:

Tabel 5. Rata-rata nilai Ujicoba kelompok kecil

\begin{tabular}{|l|c|}
\hline \multicolumn{1}{|c|}{ Komponen } & $\begin{array}{c}\text { Nilai Rata- } \\
\text { rata }\end{array}$ \\
\hline Materi & 2,73 \\
\hline Verbal & 3,05 \\
\hline Visual & 2,87 \\
\hline Video-audio & 3,18 \\
\hline Evaluasi & 3,20 \\
\hline Rata-rata & $\mathbf{3 , 0 1}$ \\
& (Baik) \\
\hline
\end{tabular}

Berdasarkan hasil ujicoba yang dilakukan terhadap 10 orang siswa diperoleh skor rata-rata keseluruhan 3,01. Hasil ini menyatakan bahwa platform edmodo dari segi materi, verbal, visual, video-audio dan evaluasi sudah baik. Selanjutnya dilakukan ujicoba kelompok besar dan hasil ujicoba ditampilkan pada tabel berikut:

Tabel 6. Rata-rata Nilai Ujicoba Kelompok Besar

\begin{tabular}{|c|c|}
\hline Komponen & $\begin{array}{l}\text { Nilai Rata- } \\
\text { rata }\end{array}$ \\
\hline Materi & 3,38 \\
\hline Verbal & 3,37 \\
\hline Visual & 3,33 \\
\hline Video-audio & 3,45 \\
\hline Evaluasi & 3,45 \\
\hline Rata-rata & $\begin{array}{c}\mathbf{3 , 4 0} \\
\text { (Baik) }\end{array}$ \\
\hline
\end{tabular}

Berdasarkan hasil ujicoba yang dilakukan terhadap dua puluh empat orang siswa diperoleh skor rata-rata keseluruhan 3,40. Hasil ini menyatakan bahwa pengembangan pembelajaran berbasis blended learning pada mata pelajaran etimologi multimedia dari segi materi, verbal, visual, video-audio dan evaluasi sudah baik. 


\section{Pembahasan}

Hasil belajar merupakan salah satu indikator untuk menguji efektivitas penggunaan platform edmodo dalam pengembangan pembelajaran berbasis blended learning. Pengujian efektivitas pada penelitian ini dilihat dari post test yang dilakukan pada 24 orang siswa kelas $\mathrm{X}$ di SMK Fransiskus 1 jurusan multimedia pada tahun pelajaran 2017/2018 dibandingkan dengan pre test yang lebih dahulu dilakukan. Validasi soal etimologi multimedia dari 60 soal yang dinyatakan valid ada 47 soal. Validasi dilakukan dengan menggunakan program Microsoft Excel yang dapat dilihat pada lampiran. Reabilitas soal 0,9. Perbandingan nilai antara pre test dan post test diperoleh grafik perbandingan berikut.

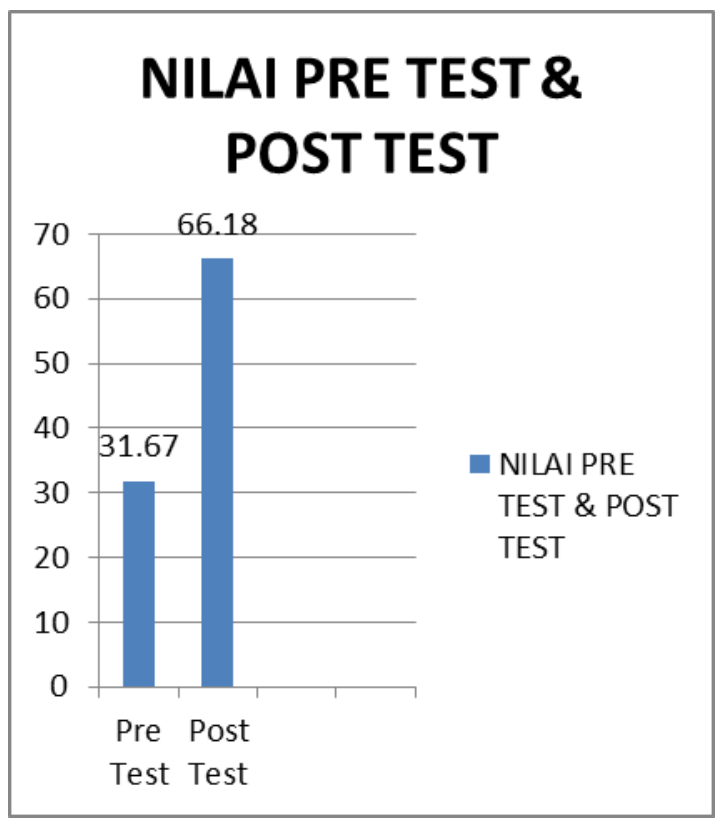

Gambar 1. Grafik Nilai Pre test dan Post test

Dari perhitungan di atas maka nilai ratarata post test etimologi multimedia lebih tinggi daripada nilai pre test sebelum siswa diperkenalkan pembelajaran berbasis blended learning, dengan demikian pengembangan pembelajaran berbasis blended learning pada mata pelajaran etimologi multimedia secara efektif dapat meningkatkan hasil belajar siswa berdasarkan indikator pembelajaran yang telah ditentukan.

Tujuan penelitian dan pengembangan ini adalah menghasilkan model pembelajaran berbasis blended learning dengan memanfaatkan platform edmodo pada mata pelajaran etimologi. Dari proses penelitian dan pengembangan yang dilakukan telah menghasilkan apa yang disebut model pembelajaran berbasis blended learning yang diterapkan pada mata pelajaran etimologi multimedia yang mencakup silabus, rencana pelaksanaan pembelajaran (RPP), alat evaluasi dan produk pembelajaran berupa file, pdf, powerpoint, powtoon dan video yang akan diupload pada platform edmodo.

Blended learning adalah salah satu revolusi dibidang pendidikan berbasis teknologi internet yang bisa digunakan untuk pendidikan jarak jauh maupun penunjang pembelajaran. Dalam pelaksanaannya meskipun sama-sama memanfaatkan teknologi internet blended learning tidak mewajibkan pembelajaran dengan menggunkan metode online saja, tetapi pelaksanaan pembelajaran harus tetaap dikombinasikan dengan metode tatap muka.

Tujuan penelitian dan pengembangan ini adalah menghasilkan model pembelajaran berbasis blended learning dengan memanfaatkan platform Edmodo pada mata pelajaran Etimologi Multimedia. Dari proses penelitian dan pengembangan yang dilakukan telah menghasilkan apa yang disebut model pembelajaran berbasis 
blended learning yang diterapkan pada mata pelajaran Etimologi Multimedia yang mencakup Silabus, Rencana Pelaksanaan Pembelajaran (RPP), Alat Evaluasi dan Produk pembelajaran berupa file ,pdf, powerpoint, powtoon dan video yang akan diupload pada platform Edmodo.

Blended learning adalah salah satu revolusi di bidang pendidikan berbasis teknologi internet yang bisa digunakan untuk pendidikan jarak jauh maupun penunjang pembelajaran. Dalam pelaksanaannya meskipun sama-sama memanfaatkan teknologi internet, blended learning tidak mewajibkan pembelajaran dengan menggunakan metode online saja, tetapi pelaksanaan pembelajaran harus tetap dikombinasikan dengan metode tatap muka. Sehingga proses pembelajaran akan tetap terawasi dan terkontorl, misalnya siswa yang kesulitan dalam memahami saat online pada malam hari keesokan harinya langsung dapat bertanya pada guru tentang kesulitannya tersebut, motivasi belajar siswa akan tetap terjaga. Sehingga peran guru sebagai pengawas dan pengelola pendidikan pun masih tetap terjaga.

Dalam melaksanakan blended learning terdapat faktor utama yaitu : (1) sarana dan prasarana, (2) guru perlu meningkatkan kemampuannya dalam bidang TIK dengan cara membaca dan berlatih mandiri maupun melalui pelatihan formal, dan (3) siswa perlu mendapatkan akses terhadap komputer dan internet dan memiliki kemampuan memanfaatkan E-Learning. Agar pembelajaran dapat optimal ketiga faktor tersebut harus dapat terpenuhi dan terlaksana dengan baik, pihak sekolah dan institusi pendidikan harus berupaya mendukung dan memenuhi sarana dan prasarana untuk mendukung guru dalam mengembangkan kemampuannya dalam bidang TIK dan mengupayakan siswa mendapatkan akses terhadap komputer dan internet. Jika upaya itu terlaksana maka pelaksanaan blended learning akan dapat berjalan dengan optimal.

Pelaksanaan pembelajaran blended learning terlihat masih mengalami kesulitan dalam membedakan pelaksanaan distance learning dan blended learning. Dalam menerapkan blended learning dengan strategi full online (online penuh), tentu akan sama saja dengan distance learning dimana peran guru kurang begitu menonjol, yang menjadi pembeda antara distance learning dan blended learning adalah komposisi yang tepat dalam mengelola strategi, online, offline dan tatap muka, pembagian komposisi itu mutlak dilakukan oleh guru agar tujuan pembelajaran dapat tercapai. Sehingga perlu dikaji bagaimanakah proses pelaksanaan blended learning dan bagaimanakah mengoptimalkan blended learning agar dapat berjalan dengan efektif dan efisien.

Perencanaan pembelajaran berbasis blended learning pada mata pelajaran Etimologi Multimedia dengan memanfaatkan 
platform Edmodo memiliki kekuatan dan kelemahan program yang akan dijabarkan sebagai berikut.

\section{Kekuatan Program}

Mengingat program ini dikembangkan berbasis internet dan menggunakan platform Edmodo yang sudah teruji keandalannya, maka platform ini memiliki beberapa keunggulan, diantaranya : 1) Guru dan peserta didik dapat melaksanakan proses pembelajaran berbasis blended learning dengan menggunakan platform Edmodo dengan memanfaatkan beberapa fitur yang ada pada Edmodo untuk mengupload dan mendownload materi yang akan dipelajari dalam pembelajaran tatap muka maupun pembelajaran online; 2) Peserta didik dapat memanfaatkan fitur chatting pada platform Edmodo untuk dapat berkomunikasi dengan guru; 3) Platform Edmodo menyediakan lingkungan dimana mengajar dan belajar dapat menghasilkan kegembiraan siswa, siswa menjadi lebih mandiri, tanpa melupakan standar pengukuran keberhasilan siswa; 4) Pada hakikatnya platform Edmodo ini mudah dipelajari dan mudah digunakan terutama bagi para guru yang menganggap dirinya berada di luar basis pengetahuan teknologi yang berkembang saat ini. 5) Evaluasi yang dilakukan khususnya evaluasi yang menggunakan tes obyektif, memungkinkan dilakukan pengolahan skor secara otomatis, khususnya pada bentuk soal pilihan ganda.

\section{Kelemahan Program}

Di samping kekuatan-kekuatan di atas, program blended learning ini tidak luput dari kelemahan. Beberapa kelemahan yang tampak selama proses evaluasi adalah: 1) Program ini memerlukan jaringan dan koneksi internet yang stabil, terutama pada saat melakukan proses pembelajaran online dan mengerjakan tes. Kalau jaringan dan koneksi tidak stabil, pada saat kita melakukan diskusi online, sering tertinggal/ lambat dalam memposting pendapat, sehingga apa yang disampaikan menjadi tidak relevan. Lebih parah lagi kalau ketidakstabilan itu terjadi pada saat mengerjakan tes, bisa jadi pada saat tes belum selesai dikerjakan jaringan dan koneksinya terputus, sehingga tidak semua soal diselesaikan. Kondisi ini tentunya bermasalah bagi peserta didik; 2) Sistem evaluasi dalam bentuk essay test tidak fleksibel dalam pemeriksaan. Dengan sistem evaluasi dalam bentuk tes essai secara online, jawaban peserta didik akan terkirim dan terekam dalam database (server), namun essay test tidak bisa diperiksa secara otomatis, maka pemeriksaannya tetap harus manual. Jawaban peserta didik harus dibuka dan dibaca satu-persatu. Kondisi ini menjadikan program tidak efisien, tidak fleksibel dalam komponen penilaian terhadap keterlibatan dan peningkatan hasil belajar siswa. Dalam pemeriksaan guru sangat bergantung pada akses internet. Pada saat pemeriksaan harus selalu membuka program dan memberi skor pada setiap jawaban untuk disimpan kembali di dalam database (server) agar hasilnya bisa dilihat oleh siswa; 3) Dengan sistem evaluasi yang dilakukan secara online, memungkinkan mereka mengerjakan tes dengan bekerjasama, terutama jika tes 
dilakukan pada jam-jam kuliah. Kelemahan lainnya memungkinkan mereka membuka buku untuk menjawab pertanyaan (soal).

\section{KESIMPULAN}

Berdasarkan hasil penelitian dan pembahasan yang telah dilakukan, maka dapat disimpulkan bahwa: (1) Penelitian awal dilakukan di SMK Fransiskus 1 kelas $\mathrm{X}$ jurusan multimedia yang melibatkan 24 siswa. Penelitian awal dilakukan untuk mendapatkan informasi kebutuhan siswa untuk merancang model pembelajaran berbasis blended learning. (2) Pengembangan pembelajaran berbasis blended learning pada mata pelajaran etimologi multimedia menggunakan model pengembangan pemnbelajaran Dick dan Carey dengan memanfaatkan platform edmodo.

Pengembangan pembelajaran berbasis blended learning yang terdiri dari file pdf, ppt, word, powtoon dan video dapat diterima dengan sangat baik oleh siswa kelas $\mathrm{X}$ jurusan multimedia. (4) Pembelajaran etimologi multimedia sangat menarik karena model pembelajaran yang digunakan sangat bervariasi sehingga memotivasi siswa untuk belajar secara mandiri. (5) minat dan ketrampilan siswa mengalami peningkatan namun hasil belajar siswa belum maksimal. kriteria ketuntasan minimal (KKM) etimologi multimedia adalah 70 . sedangkan ratarata hasil post test yang telah dilakukan mendapat hasil 66,18. hal Ini disebabkan karena model pembelajaran berbasis blended learning masih tergolong baru pada SMK Fransiskus 1, sehingga membutuhkan proses yang tidak sebentar.

\section{REFERENSI}

Akgunduz, Devrim \& Orhan Akinoglu, The Effect of Blended learning and Social Media-Supported Learning On The Students' Attitude and Self-Directed Learning Skills In Science Education, TOJET: The Turkish Online Journal of Educational Technology - April 2016, volume 15 issue 2

Anan Sutisna. Pengembangan Model Pembelajaran Blended learning pada Pendidikan Kesetaraan Program Paket C dalam Meningkatkan Kemandirian Belajar. Jurnal Teknologi Pendidikan Vol. 18, No. 3 Tahun 2016.

Bibi, sarah \& Jati, Handaru. Efektivitas Model Blended Learning Terhadap Motivasi Dan Tingkat Pemahaman Mahasiswa Mata Kuliah Algoritma Dan Pemrograman. Jurnal Pendidikan Vokasi UNY Vol 5, Nomor 1, Februari 2015

Borg and Gall. Educational Research; an introduction. (New York: Longman, 1983

Dick, Walter, Lou Carey, dan James O'Carey. The systematic Design of Instructional; 6th editions. Boston: Pearson Allyn and Baron, 2005.

Gustafson, Kent L. and Robert Maribe Branch. Survey of Instructional Development Models. New York: Eric Clearinghouse on Information and Technology, Syracus University, 2002. 
Izuddin Syarif 2012. Pengaruh Model Blended learning Terhadap Motivasi dan Prestasi Belajar Siswa SMK. Jurnal Pendidikan Vokasi, Vol 2, Nomor 2

Iga Setia Utami 2017. Pengujian Validitas Model Blended learning Di Sekolah Menengah Kejuruan. Jurnal Ilmiah Pendidikan Teknik Elekto Vol. 2, No. 1

Khan, Badrul, Managing E-Learning Strategies : Design, Delivery, Implementation and Evaluation. Hershey : Information Science Publishing. 2005.

Nur Aeni, dkk 2017. Pengembangan Model Blended learning Berbasis Masalah Pada Mata Pelajaran Sistem Komputer. Innovative Journal of Curriculum and Educational Technology 6 (2)

Prawiradilaga Dewi Salma. Wawasan Teknologi Pendidikan. Jakarta: Kencana Prenada, 2012.

Prendergast, Gerard. Blended Collaborative Learning : Online Teaching Of Online Educators. London : GlobalEducator. 2004.

Putra, Arif Permana. Pengaruh Penerapan Model Blended learning Terhadap Prestasi Belajar Sejarah Siswa, Jurnal Candrasangkala Volume 1 Nomor 1 November 2015

Seels, Barbara B., Rita C. Richey. Teknologi Pembelajaran: Definisi dan Kawasannya terjemahan Dewi S
Prawiradilaga, Raphael Rahardjo dan Yusufhadi Miarso. Jakarta: Unit Percetakan UNJ, 1994.

Setyosari, Punaji. Metode Penelitian Pendidikan \& Pengembangan. Jakarta : Kencana Prenadamedia Group. 2013.

Syaiful Arif 2013, Pembelajaran Pengetahuan Dasar Komputer Berbasis Blended learning Pada Program Studi Agribisnis STIPER AMUNTAI, Jurnal Pendidikan Vokasi,

Thorne, Kaye. Blended learning : how to integrate online and traditional learning. Great Britain and the United States: Kogan Page. 2003. 